Jurnal Manajemen dan Bisnis Jayakarta, Volume 1, No. 2, Januari 2020

\title{
DETERMINASI LIKUIDITAS TERHADAP PROFITABILITAS PADA PERUSAHAAN SEKTOR MAKANAN DAN MINUMAN
}

\author{
Ruth Lam Dorma \\ BPJS Kesehatan \\ ruth_askes@yahoo.com
}

\begin{abstract}
ABSTRAK
Penelitian ini bertujuan untuk mengukur seberapa mampu perusahaan menghasilkan laba dari proses operasional yang telah dilaksanakan untuk menjamin kelangsungan perusahaan di masa yang akan datang dengan menggunakan rasio likuiditas. Teknik pengambilan sampel yang digunakan adalah purposive sampling. Populasi dalam penelitian ini yaitu perusahaan pada sektor makanan dan minuman yang terdaftar di Bursa Efek Indonesia periode tahun 2016-2018. Jenis Penelitian yang digunakan adalah penelitian deskriptif kuantitatif dengan metode kausal-komparatif. Hasil analisis ini menunjukkan bahwa likuiditas secara simultan berpengaruh terhadap profitabilitas. Disarankan agar rasio likuiditas terus meningkat sehingga diharapkan akan berpengaruh terhadap peningkatan profitabilitas.
\end{abstract}

Kata kunci: likuidtas (current rasio, cash ratio, net working capital) dan profitabilitas 
Jurnal Manajemen dan Bisnis Jayakarta, Volume 1, No. 2, Januari 2020

\section{PENDAHULUAN}

Rasio likuiditas dan dalam memprediksi perubahan laba pada perusahaan Food and Beverages yang terdaftar di Bursa Efek Indonesia adalah dengan Current Ratio (rasio lancar). Current Ratio adalah rasio yang mengukur kemampuan perusahaan memenuhi utang jangka pendeknya dengan menggunakan aktiva lancarnya. Rasio lancar dihitung dengan membagi antara aktiva lancar dengan kewajiban lancar. Aktiva lancar umumnya meliputi kas, sekuritas, piutang usaha, dan persediaan. Sedangkan kewajiban lancar terdiri atas utang usaha, wesel tagih jangka pendek, utang jatuh tempo yang kurang dari satu tahun, akrual pajak, dan beban-beban akrual lainnya. Meskipun dikalangan beberapa pihak beranggapan likuiditas tidak berpengaruh secara signifikan terhadap pertumbuhan laba, karena perusahaan tidak dapat mendayakan hutangnya dalam memperoleh laba, namun beberapa pihak juga ada yang beranggapan bahwa likuiditas sangat berpengaruh terhadap pertumbuhan laba. Pendapatan perusahaan yang diperoleh dari kegiatan penjualan yang lebih besar dibandingkan total hutang-hutang jangka pendeknya maka perusahaan akan dipastikan mampu membayar hutanghutangnya. Dengan kata lain melalui analisis rasio lancar (current ratio) yang merupakan perbandingan antara aktiva lancar, kewajiban lancar sebagai ukuran yang paling umum digunakan untuk mengetahui kesanggupan suatu perusahaan mampu memenuhi kewajiban jangka pendeknya. Maka kelangsungan kontinuitas operasi perusahaan tidak akan terganggu, dan pendapatan yang diperoleh menjadi meningkat dan laba yang diperoleh tetap besar. perusahaan yang berusaha lebih keras untuk memperbaiki manajemen bisnisnya supaya agar tetap bertahan untuk lancarnya kelangsungan hidup perusahaan tersebut, yaitu dengan cara meningkatkan kondisi keuangan perusahaan yang pada dasarnya dapat dinilai dari berbagai aspek dan salah satu aspek yang berpengaruh terhadap perkembangan dari suatu perusahaan adalah penilaian dari aspek profitabilitasnya karena profitabilitas menggambarkan kemampuan dari perusahaan tersebut untuk memperoleh laba, yaitu usaha agar modal yang digunakan bisa menghasilkan laba yang maksimal.

Profitabilitas mempunyai peran penting dalam perusahaan sebagai cerminan masa depan apakah perusahaan mempunyai prospek yang baik di masa mendatang. Bagi perusahaan masalah profitabilitas sangatlah penting. Bagi 
Jurnal Manajemen dan Bisnis Jayakarta, Volume 1, No. 2, Januari 2020

pemimpin perusahaan profitabilitas sektor makanan dan minuman digunakan untuk melihat seberapa besar kemajuan atau berhasil tidak perusahaan yang dipimpinnya. Tujuan penelitian ini adalah untuk mengetahui pengaruh Current Ratio secara parsial terhadap pertumbuhan laba untuk periode satu tahun ke depan dan untuk mengetahui pengaruh Current Ratio secara simultan terhadap pertumbuhan laba untuk periode satu tahun ke depan.

\section{KAJIAN LITERATUR}

Menurut PSAK No. 1 (2015: 1.3), "Laporan keuangan adalah hasil akhir dari proses akuntansi sebuah perusahaan yang memberikan informasi keuangan suatu perusahaan yang berguna bagi pihak internal maupun eksternal perusahaan". Menurut Kasmir (2014: 7):

Laporan keuangan adalah laporan yang menunjukkan kondisi keuangan perusahaan pada saat ini atau dalam suatu periode tertentu. Jadi, disimpulkan bahwa laporan keuangan adalah laporan yang dapat menggambarkan kondisi keuangan perusahaan selama periode tertentu yang dapat berguna pihak-pihak yang membutuhkan laporan keuangan tersebut. Rasio dalam analisis laporan keuangan adalah angka yang menunjukan hubungan antara suatu unsur dengan unsur yang lainnya dalam laporan keuangan. Hubungan antara unsur-unsur laporan keuangan tersebut dinyatakan dalam bentuk matematis yang sederhana. Menurut Irham Fahmi (2012:109) manfaat yang bisa diambil dengan dipergunakannya rasio keuangan, yaitu:

1. Analisi rasio keuangan sangat bermanfaat untuk dijadikan sebagai alat menilai kinerja dan prestasi perusahaan.

2. Analisis rasio keuangan sangat bermanfaat bagi pihak manajemen sebagai rujukan untuk membuat perencanaan.

3. Analisis rasio keuangan dapat dijadikan sebagai alat untuk mengevaluasi kondisi suatu perusahaan dari perspektif keuangan.

4. Analisis rasio keuangan juga bermanfaat bagi para kreditor dapat digunakan untuk memperkirakan potensi risiko yang akan dihadapi dikaitkan dengan adanya jaminan kelangsungan pembayaran bunga dan pengembalian pokok pinjaman.

5. Analisis rasio keuangan dapat dijadikan sebagai penilaian bagi pihak Stakeholder organisasi.

Rasio likuiditas adalah rasio yang menunjukkan kemampuan perusahaan dalam memenuhi kewajiban atau membayar utang jangka pendeknya. Rasio inilah yang dapat digunakan untuk mengukur seberapa llikuidnya suatu 
Jurnal Manajemen dan Bisnis Jayakarta, Volume 1, No. 2, Januari 2020

perusahaan. Jika perusahaan mampu memenuhi kewajibannya berarti perusahaan tersebut likuid, sedangkan jika perusahaan tidak mampu memenuhi kewajibannya berarti perusahaan tersebut ilikuid. Menurut Kasmir (2014:129) Likuiditas (liquidity ratio) merupakan rasio yang menggambarkan atau mengukur kemampuan perusahaan dalam memenuhi kewajiban (utang) jangka pendek. Artinya apabila perusahaan ditagih, perusahaan akan mampu untuk memenuhi utang tersebut terutama utang yang sudah jatuh tempo. Sedangkan menurut Munawir (2010: 5) Dua daftar yang tersusun oleh Akuntan pada akhir periode untuk suatu perusahaan. Kedua daftar itu adalah daftar neraca atau daftar posisi keuangan dan daftar pendapatan atau daftar rugi-laba. Pada waktu akhir-akhir ini sudah menjadi kebiasaan bagi perseroan-perseroan untuk menambahkan daftar ketiga yaitu daftar surplus atau daftar laba yang tak dibagikan (laba yang ditahan).

Pentingnya likuiditas dapat dilihat dari pertimbangan dampak kemampuan perusahaan yang memenuhi utang (kewajiban) jangka pendeknya. Tetapi jika likuiditas hanya dipandang sebagai ukuran kinerja, perusahaan memberikan informasi yang lebih mendalam untuk menjelaskan rendahnya kinerja disbanding perusahaan yang mempunyai rasio likuiditas tinggi. Rasio lancar dapat pula dikatakan sebagai bentuk untuk mengukur tingkat keamanan (margin of safety) suatu perusahaan. Dalam rasio ini akan diketahui sejauh mana aktiva lancar perusahaan dapat digunakan untuk menutupi kewajiban jangka pendek atau hutang lancarnya. Semakin besar perbandingan aktiva lancar dengan hutang lancar maka artinya perusahaan semakin tinggi pula kemampuan perusahaan dalam menutupi kewajiban hutang lancarnya. Rumus current ratio adalah:

$$
\text { Rasio Lancar }=\frac{\text { Total Aktiva Lancar }}{\text { Total Hutang Lacar }}
$$

Apabila hasilnya menunjukkan Rasio lancar (current rasio) 1:1 atau 100\% artinya aktiva lancar dapat menutupi kewajiban jangka pendek dan akan lebih aman jika rasio lancar diatas satu atau diatas $100 \%$ maka perusahaan akan mampu membayar hutang lancarnya tanpa mengganggu operasi perusahaan. Tingginya Rasio lancar dapat menunjukkan adanya uang kas yang berlebihan dibandingkan dengan aktivitas atau kebutuhan atau adanya unsur aktiva yang rendah likuiditasnya seperti persediaan yang berlebihan. Tingginya tingkat rasio juga dikhawatirkan akibat tidak digunakan secara secara efektif oleh perusahaan. Suatu perusahaan yang memiliki rasio Lancar sebesar 2 kali ini 
Jurnal Manajemen dan Bisnis Jayakarta, Volume 1, No. 2, Januari 2020

dianggap sebagai posisi nyaman dalam keuangan bagi kebanyakan perusahaan. Namun pada dasarnya, Rasio Lancar yang dapat diterima ini bervariasi antara satu industri dengan industri lainnya. Bagi kebanyakan industri, Rasio Lancar sebesar 2 kali sudah dianggap dapat diterima atau "Acceptable". Nilai rendah pada Rasio Lancar (nilai yang kurang dari 1 kali) menunjukan bahwa perusahaan mungkin mengalami kesulitan untuk memenuhi kewajiban lancarnya. Namun Investor atau calon kreditur juga harus memperhatikan arus kas operasi perusahaan agar bisa lebih memahami tingkat likuiditas perusahaannya. Apabila Rasio Lancar Perusahaan rendah, para Investor atau calon kreditur dapat menilai kesehatan keuangan perusahaan yang bersangkutan dengan kondisi arus kas (cash flow) operasional pada perusahaan tersebut. Jika rasio lancar terlalu tinggi (nilai yang lebih dari 2 kali), maka perusahaan tersebut mungkin tidak menggunakan aset lancar atau fasilitas pembiayaan jangka pendeknya secara efisien.

Profitabilitas merupakan salah satu pengukuran kinerja bagi suatu perusahaan. Profitabilitas menunjukkan kemampuan suatu perusahaan dalam menghasilkan laba selama periode tertentu pada tingkat penjualan, aset, dan modal saham tertentu.
Jika sebuah perusahaan berhasil meningkatkan profitabilitasnya, dapat diartikan bahwa perusahaan tersebut mampu mengelola asetnya secara efektif dan efisien, sehingga mampu tetap mempertahankan tingkat risiko bisnisnya, maka semakin tinggi profitabilitas akan menyebabkan semakin tinggi nilai perusahaan. Oleh karena itu untuk dapat meningkatkan nilai perusahaan maka pihak manajemen perlu meningkatkan profitabilitas perusahaan.

Menurut Hery (2017: 7), "Profitabilitas merupakan salah satu dasar penilaian kondisi perusahaan untuk mengukur efektivitas manajemen berdasarkan hasil pengembalian yang diperoleh dari penjualan dan investasi." Profitabilitas juga mempunyai arti penting dalam usaha mempertahankan kelangsungan hidup perusahaan untuk jangka panjang, karena profitabilitas untuk menunjukkan bahwa perusahaan tersebut mempunyai prospek yang baik dimasa yang akan datang atau tidak.

\section{METODE}

Penelitian ini dilakukan dengan menggunakan penelitian kuantitatif karena penelitian ini bersifat menganalisis laporan keuangan perusahaan sektor makanan dan minuman yang terdaftar di Bursa Efek 
Jurnal Manajemen dan Bisnis Jayakarta, Volume 1, No. 2, Januari 2020

Indonesia dan menafsirkan hasilnya dalam bentuk angka-angka. Menurut Sofar Silaen (2018: 18), "Penelitian kuantitatif adalah metodologi kuantitatif sebagai prosedur penelitian yang menghasilkan data berupa angka-angka dan umumnya dianalisis dengan mengunakan statistik deskriptif atau inferensial." Pada penelitian ini, metode penelitian kuantitatif digunakan untuk meneliti pada sampel dengan menggunakan instrumen penelitian dengan tujuan untuk menguji hipotesis yang telah dirumuskan. Variabel dependen yang digunakan dalam penelitian ini adalah laba. Pertumbuhan laba adalah rasio yang menunjukkan kemampuan perusahaan meningkatkan laba bersih dibanding tahun sebelumnya. Laba yang digunakan adalah laba setelah pajak (earning after tax). Variabel indipenden dalam penelitian ini adalah Current Ratio ( Rasio Lancar). teknik pengumpulan data dengan cara mengambil data melalui yang ada di Bursa Efek. Adapun data yang dikumpulkan adalah data laporan keuangan yang meliputi laporan neraca dan laporan laba rugi selama kurun waktu 4 tahun pada perusahaan Food and Beverages Public di BEI. Adapun pengolahan data pada penelitian ini dengan mengunakan analisis sebagai berikut :

\section{Uji Asumsi Klasik}

Untuk mengetahui apakah model regresi benar-benar menunjukkan hubungan yang signifikan dan mewakili (representatif), maka model tersebut harus memenuhi uji asumsi klasik regresi.

\section{Analisis Regresi linier Berganda}

Tteknik analisis regresi linier berganda untuk memperoleh gambaran yang menyeluruh mengenai hubungan antara variabel satu dengan variabel lain.

\section{Analisis Koefisien Korelasi}

Analisis korelasi parsial digunakan bila peneliti ingin memengaruhi pengaruh atau hubungan antara salah satu variabel independen terhadap variabel dependen, sedangkan variabel independen lainnya dibuat konstan (dikendalikan). Analisis Uji Koefisian Korelasi Berganda melibatkan untuk dua variabel, teknik statistic yang digunakan adalah koefisien korelasi berganda, koefisien parsial, dan koefisien determinasi. Koefisien korelasi berganda diberi symbol $\mathrm{R}$ adalah angka yang menunjukan arah dan keeratan hubungan antara dua atau lebih variabel independen $\left(\mathrm{X}_{1}, \mathrm{X}_{2}, \ldots, \mathrm{X}_{\mathrm{k}}\right)$ secara simultan atau secara bersama-sama dengan satu variabel dependen (Y).

\section{Analisis Uji Hipotesis}

Dalam analisis berganda akan dilakukan Uji t, dan Uji F. 
Jurnal Manajemen dan Bisnis Jayakarta, Volume 1, No. 2, Januari 2020

\section{Koefisien Determinasi $\left(\mathbf{R}^{2}\right)$}

Koefisien determinasi $\left(\mathrm{R}^{2}\right)$ pada intinya mengukur besarnya variance nilai variabel dependen yang dijelaskan oleh variabel independen. Nilai $\left(\mathrm{R}^{2}\right)$ mempunyai range antara nol dengan sampai satu $\left(0 \leq \mathrm{R}^{2}\right.$ $\leq 1)$. Apabila nilai $\mathrm{R}^{2}$ mendekati 1 maka menunjukan semakin besar nilai variabel independen secara keseluruhan menjelaskan variabel dependen. Sebaliknya, apabila nilai $\mathrm{R}^{2}$ mendekati 0 , maka variabel independen secara keseluruhan tidak dapat menjelaskan variabel dependen.

\section{HASIL DAN PEMBAHASAN}

Penelitian Variabel Current Ratio (CR) memiliki nilai minimum sebesar 0,51 $\%$ yang dimiliki PT Multi Bintang Indonesia dan nilai maksimum sebesar 8,64 $\%$ yang dimiliki PT Delta Djakarta. Nilai rata-rata dari Current Ratio (CR) sebesar 2,2007\% dan standar deviasi Current Ratio (CR) sebesar 1,60132\% dengan jumlah pengamatan sebanyak 56 data $(\mathrm{N})$. Variabel Pertumbuhan Laba memiliki nilai minimum sebesar $-6,30 \%$ dan nilai maksimum sebesar 2,05\%. Nilai rata-rata dari Pertumbuhan Laba sebesar -0,0061\% dan standar deviasi Pertumbuhan Laba sebesar 1,15423 \% dengan jumlah pengamatan sebanyak 56 data $(\mathrm{N})$.

\section{Uji Asumsi Klasik}

Berdasarkan hasil uji normalitas menunjukkan besarnya KolmogorovSmirnov (K-S) adalah 1,678 dan signifikansi pada 0,070 nilai signifikansi lebih besar dari 0.05. Sehingga dapat disimpulkan bahwa data dalam model regresi berdistribusi secara normal. Penelitian ini juga bebas dari adanya multikolinearitas, hal ini bisa dilihat dengan membandingkan dengan nilai tolerance dan VIF. Masing-masing variabel bebas yang digunakan dalam penelitian ini memiliki nilai tolerance diatas nilai 0,20 yaitu untuk likuiditas nilai tolerance 0,438 . Jika dilihat dari VIF-nya, bahwa masing-masing variabel bebas dibawah nilai 5 yaitu untuk likuiditas VIF 2,284. Dengan demikian, dapat disimpulkan bahwa tidak terjadi multikolinieritas pada variabel bebas. Berdasarkan Output Scatterplot, terlihat bahwa titik-titik menyebar dan tidak membentuk pola tertentu yang jelas. Sehingga dapat disimpulkan bahwa tidak terjadi masalah heteroskedastisitas. Berdasarkan nilai Durbin Watson $(\mathrm{DW})=$ 1,781. Sedangkan nilai $4-\mathrm{d}_{\mathrm{U}}=4-1,7501$ $=2,2499$. Dengan demikian $\mathrm{DW}>\mathrm{d}_{\mathrm{U}}$ atau $1,781>1,7501$ dan DW < $(4-d u)$ atau 1,781<2,2499. Dengan demikian du $<$ DW 
Jurnal Manajemen dan Bisnis Jayakarta, Volume 1, No. 2, Januari 2020

$<4-$ du atau $1,7501<1,781<2,2499$

berarti berada pada daerah tidak ada autokorelasi, terima hipotesis.

\section{Analisis Regresi Linear Berganda}

Nilai konstanta a $=4,147$ memberikan arti bahwa jika variabel bebas diabaikan atau dengan kata lain jika tidak ada variasi pada likuiditas maka profitabilitas akan naik senilai 4,147. Nilai koefisien $\mathrm{b} 1=0,049$ hal ini berarti bahwa setiap peningkatan satu satuan pada likuiditas dengan asumsi variabel lainnya konstan, maka profitabilitas akan mengalami peningkatan sebesar 0,049 satuan dan bergerak ke arah yang sama (arah positif).

\section{Analisis Koefisien Korelasi}

Nilai koefisien korelasi (r) pada variabel likuiditas sebesar 0,523. Nilai 0,523 berada dalam rentang 0,40 s.d. 0,60, berarti hubungan antara likuiditas dengan profitabilitas dikategorikan cukup erat. Nilai signifikansi $(\alpha)$ pada variabel likuiditas sebesar $0,031<0,05$, berarti terdapat hubungan likuiditas dengan profitabilitas.

\section{Hasil Uji Hipotesis}

Berdasarkan Kurva di atas, nilai t hitung $=4,980$. Nilai 4,980>2,16037, berada di

dalam daerah penolakan Ho, sehingga $\mathrm{H}_{1}$ diterima berarti terdapat pengaruh antara variabel likuiditas terhadap profitabilitas perusahaan sektor makanan dan minuman yang terdaftar di Bursa Efek Indonesia Tahun 2016-2018 (Y).

\section{Koefisien Determinasi}

Dalam penelitian ini menggunakan variabel bebas sehingga koefisien determinasi adalah nilai Adjusted $\mathrm{R}$ square. Tabel di atas menghasilkan nilai koefisien determinasi atau Adjusted $\mathrm{R}$ square $=0,779$. Dengan demikian besarnya konstribusi likuiditas secara simultan terhadap profibilitas adalah sebesar 77,90 $\%$ sedangkan sisanya $22,10 \%$ dipengaruhi oleh faktor-faktor lainnya yang tidak diteliti.

\section{KESIMPULAN}

Likuiditas berpengaruh terhadap profitabilitas pada perusahaan sektor makanan dan minuman yang terdaftar di Bursa Efek Indonesia. Dan likuiditas secara simultan berpengaruh terhadap profitabilitas perusahaan sektor makanan dan minuman yang terdaftar di Bursa Efek Indonesia. 
Jurnal Manajemen dan Bisnis Jayakarta, Volume 1, No. 2, Januari 2020

Semakin tinggi tingkat rasio likuiditas diharapkan akan berpengaruh positif terhadap peningkatan profitabilitas. Bagi perusahaan diharapkan untuk senantiasa memperhatikan dan meningkatkan kinerja keuangan perusahaan terutama sektor likuiditasnya, sehingga kinerja perusahaan akan semakin mengalami peningkatan dengan ditunjukkan adanya pertumbuhan laba.

\section{REFERENSI}

Dr. Kasmir, S. M. (2019). Analisis Laporan Keuangan. Depok: Rajawali Pers.

Fahmi, I. (2015). Manajemen Kinerja Perusahaan. Jakarta.

Fatima, A. (2017). Pengaruh Profitabilitas, Likuiditas, dan Solvabilitas terhadap Kinerja Perusahaan pada sector Properti dan Real Estate. Skripsi, 16.

Fauza, M. S. (2018). Pengaruh Profitabilitas, Earning Per Share (EPS), dan Return On Assets (ROI) pada Kinerja Keuangan. Manajemen Akuntansi, 8029.

Ferdinand, A. (2014). Metode Penelitian Manajemen. Semarang: BP Universitas Diponegoro.
Handayani, R. (2018). Pengaruh Information Technology terhadap Kinerja Perusahaan, 25-28.

Hery. 2013. Akuntansi Dasar. Jakarta: Kompas Gramedia.

Ikatan Akuntansi Indonesia (IAI). 2018. Standar Akuntasi Keuangan. Per 1 Juni 2018. Jakarta: Salemba Empat.

Kasmir. 2017. Pengantar Manajemen

Keuangan. Jakarta: Kencana.

Kariyoto. 2017. Analisa Laporan

Keuangan. Malang: UB Media.

Kusuma, Hadri. 2015. DampakManajemen Laba terhadap Relevansi Informasi Akuntansi.Jakarta: Salemba Empat.

Sofar, Silaen. 2018. Metodologi Penelitian Sosial untuk Penulisan Skripsi dan Tesis. Jakarta: In Media.

Standar Akuntansi Keuangan (SAK). 2017. Laporan Posisi Keuangan, Laporan Laba Komprehensif, Laporan Perubahan Ekuitas, Laporan Arus Kas, dan Catatan atas Laporan Keuangan (PSAK No.1). Jakarta: IAI. 2018. Penarapan Bahasa Indonesia yang Benar dan Pengolahan Data dengan SPSS untuk Penulisan Skripsi. Jakarta: In Media.

www.idx.co.id. Diakses 17 November 2018. 
p-ISSN : 2715 - 0127

e-ISSN : $2715-0135$

Jurnal Manajemen dan Bisnis Jayakarta, Volume 1, No. 2, Januari 2020 